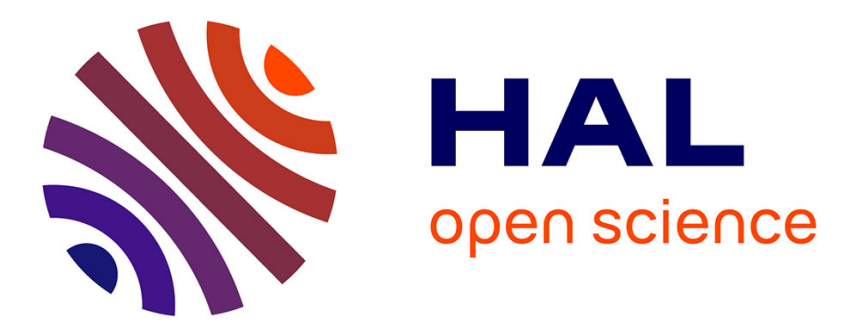

\title{
Anaerobic digestion of microalgae as a necessary step to make microalgal biodiesel sustainable.
}

Bruno Sialve, Nicolas Bernet, Olivier Bernard

\section{To cite this version:}

Bruno Sialve, Nicolas Bernet, Olivier Bernard. Anaerobic digestion of microalgae as a necessary step to make microalgal biodiesel sustainable.. Biotechnology Advances, 2009, 27 (4), pp.409-416. 10.1016/j.biotechadv.2009.03.001 . hal-00854465

\section{HAL Id: hal-00854465 \\ https://hal.inria.fr/hal-00854465}

Submitted on 27 Aug 2013

HAL is a multi-disciplinary open access archive for the deposit and dissemination of scientific research documents, whether they are published or not. The documents may come from teaching and research institutions in France or abroad, or from public or private research centers.
L'archive ouverte pluridisciplinaire HAL, est destinée au dépôt et à la diffusion de documents scientifiques de niveau recherche, publiés ou non, émanant des établissements d'enseignement et de recherche français ou étrangers, des laboratoires publics ou privés. 


\title{
Anaerobic digestion of microalgae as a necessary step to make microalgal biodiesel sustainable
}

\author{
Bruno Sialve ${ }^{\text {ac1*}}$, Nicolas Bernet ${ }^{\mathrm{a}}$, Olivier Bernard ${ }^{\mathrm{b}}$ \\ a INRA, UR050, Laboratoire de Biotechnologie de l'Environnement, Avenue des Etangs, \\ Narbonne F-11100, France \\ ${ }^{\mathrm{b}}$ INRIA-COMORE, 2004 Avenue des lucioles, BP93, Sophia-Antipolis F-06902, France \\ ${ }^{\mathrm{c}}$ : Present adresse : Naskeo Environnement, Avenue des Etangs, Narbonne F-11100, France
}

\section{Abstract}

The potential of microalgae as a source of biofuels and as a technological solution for $\mathrm{CO}_{2}$ fixation is subject to intense academic and industrial research. In the perspective of setting up massive cultures, the management of large quantities of residual biomass and the high amounts of fertilizers must be considered. Anaerobic digestion is a key process that can solve this waste issue as well as the economical and energetic balance of such a promising technology. Indeed, the conversion of algal biomass after lipid extraction into methane is a process that can recover more energy than the energy from the cell lipids. Three main bottlenecks are identified to digest microalgae. First, the biodegradability of microalgae can be low depending on both the biochemical composition and the nature of the cell wall. Then, the high cellular protein content results in ammonia release which can lead to potential toxicity. Finally, the presence of sodium for marine species can also affect the digester performance. Physico-chemical pretreatment, co-digestion, or control of gross composition are strategies that can significantly and efficiently increase the conversion yield of the algal organic matter into methane. When the cell lipid content does not exceed $40 \%$, anaerobic digestion of the whole biomass appears to be the optimal strategy on an energy balance basis, for the energetic recovery of cell biomass. Lastly, the ability of these $\mathrm{CO}_{2}$ consuming microalgae to purify biogas and concentrate methane is discussed.

Keywords: anaerobic digestion, microalgae, biochemical methane potential, codigestion, pretreatment, biogas, $\mathrm{CO}_{2}$ mitigation, biofuel

\section{Contents}

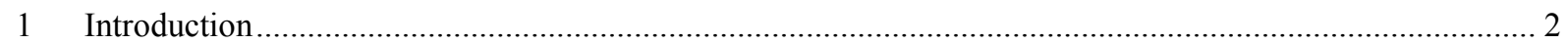

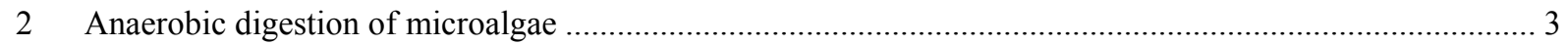

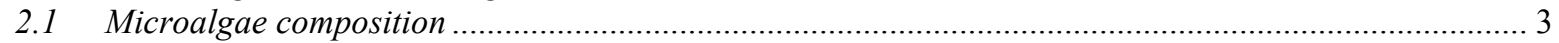

2.2 Theoretical approach of methane potential and ammonium release .................................................. 3

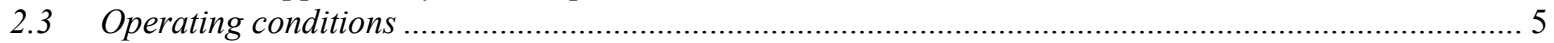

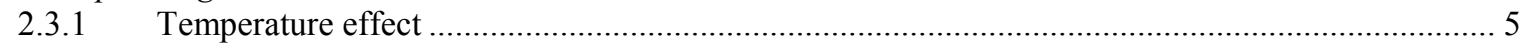

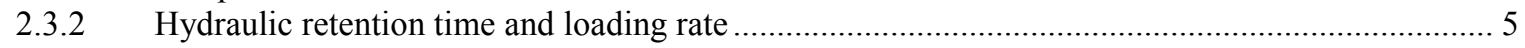

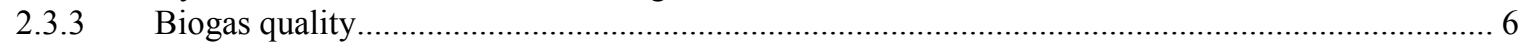

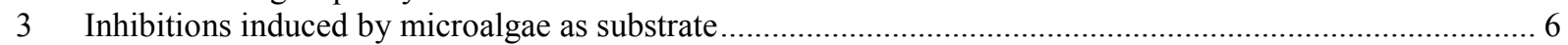

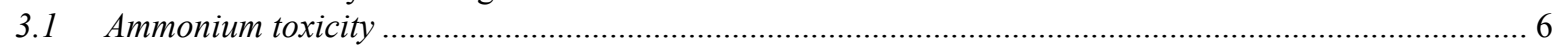

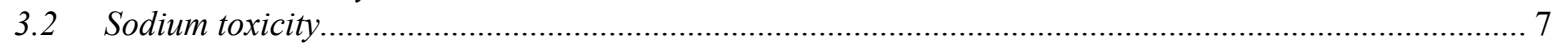

\footnotetext{
${ }^{1}$ Corresponding author. Tel $:+33$ 468425191. Fax : +33 468425160. E-mail adress : bruno.sialve@naskeo.com
} 
4 Anaerobic digestion enhancement

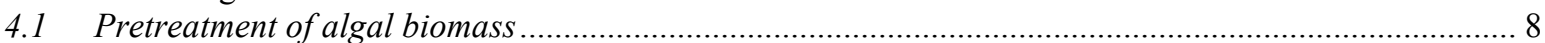

4.2 Increasing the theoretical methane potential: a metabolic approach ................................................ 8

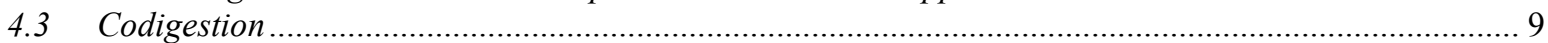

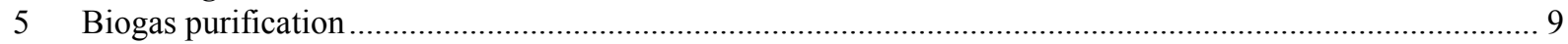

6 Is it worth to recover lipids from an energetic point of view? ........................................................... 10

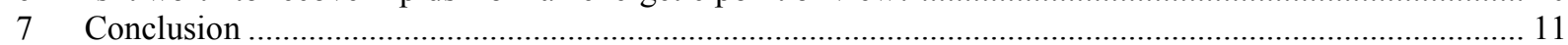

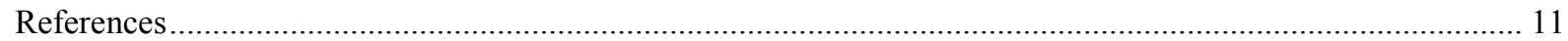

\section{Introduction}

The potential of photosynthetic microorganisms as an alternative to biofuel crops together with their potential as a promising technology for $\mathrm{CO}_{2}$ fixation is a subject of strong interest (Chisti, 2007, 2008; Li, 2008)[R3Q5]. Indeed, some eukaryotic microalgae and prokaryotic (cyanobacteria) microorganisms (abusively gathered under the term microalgae in the following) can synthesize lipids under certain environmental conditions (Metting, 1996)[R2Q1]. The perspective of large scale production of microalgae for biofuel applications is motivated by the high productivity which can be reached (Huntley and Redalje, 2007; Chisti, 2007; Carlsson et al., 2007). Chisti (2007) considered a scenario where productions up to 127 tons.ha $^{-1}$.year ${ }^{-1}$ can be achieved in high rate raceway ponds while Carlsson et al. (2007) suggested an hypothesis of 50 to 60 tons.ha ${ }^{-1}$.year ${ }^{-1}$. Photobioreactor productions of up to 150 tons.ha ${ }^{-1}$.year ${ }^{-1}$ have already been obtained (Carlsson et al., 2007), and Chisti (2007) suggested an upper value of 263 tons.ha $^{-1}$.year ${ }^{-1}$.

On the basis of an average composition of microalgae given by $\mathrm{CO}_{0.48} \mathrm{H}_{1.83} \mathrm{~N}_{0.11} \mathrm{P}_{0.01}$ (Grobbelaar, 2004) the nitrogen and phosphorus requirement per unit of surface and per year can be estimated. This leads to a nitrogen amendment that varies from 8 to 16 tons N.ha ${ }^{-}$ ${ }^{1}$.year ${ }^{-1}$. This figure is in a range 55 to 111 times higher than for rapeseed (Halleux et al. 2008)[R1Q1]. This shows that microalgae will involve huge quantities of nitrogen and phosphate for which environmental and economic impact may not be sustainable. A process to recycle nitrogen and phosphorus contained in algal waste after lipid extraction is therefore required in order to reduce the use of fertilizers. Anaerobic digestion can be an answer to this problem, since this biotechnological process can mineralise algal waste containing organic nitrogen and phosphorus, resulting in a flux of ammonium and phosphate that can then be used as a substrate for the microalgae (Olguin, 2000; Phang, 2000). Furthermore, to reach an economical balance, Chisti (2007) has shown that the resulting biomass after lipid extraction needs to be transformed into methane. Thus, if anaerobic digestion is used to process algal waste, it will not only recycle nitrogen and phosphorus but also produce methane. The energetic value[R1Q2] of the produced methane can potentially lead to an energetic balance of the microalgae to biofuel process.

Anaerobic degradation of phytoplanktonic cells is a process which takes place naturally in aquatic environments. When algal cells sink towards the anoxic and aphotic zones, they eventually die and break up. Nutrient remineralisation in these anoxic layers of aquatic environments is a key process, responsible for recycling nutritive elements. It leads to ammonium and phosphate release, which can eventually sustain growth of phytoplanktonic communities. This decomposition is a slow and incomplete process. Some cell structures can still be found in the sediments after many years, some being identified in kerogen rocks (Vandenbroucke and Largeau, 2007). Kinetics of these anaerobic degradation processes is highly dependant upon both the species degradability as well as the environmental conditions, eventually resulting in various fractions (Vandenbroucke and Largeau, 2007). The resistance of the cell wall is generally one of the limiting factors for cell digestibility (Chen, 1987; Afi et 
al. 1996; Chen and Oswald, 1998). Studies of kerogen rocks have shown that remaining fractions of TLS (TriLaminar Sheaths) are correlated to the sedimentation of chlorophycae (Derenne et al., 1992). These parietal structures characterizing some species enhances resistance to decomposition and intervene in selective safeguarding during the process of fossilization (Vandenbroucke and Largeau, 2007).

This natural process has been the subject of research studies since the fifties when energy recovery[R1Q2] of microalgae by anaerobic digestion was investigated. Goeluke and Oswald (1957) published the first study on anaerobic digestion of an algal biomass. In 1960, they proposed an integrated process associating the production of microalgae in an open pond for the treatment of sewage water and the energetic recovery[R1Q2] of the algal biomass by anaerobic digestion (Oswald and Goeluke, 1960). This scientific enthusiasm for methane production as a source of renewable energy awoke again in the nineteen seventies in relation to the first oil crisis.

The strong and recent re-interest for anaerobic digestion is correlated to its ability to treat and to convert a wide range of organic wastes into renewable energy. However, in the specific case of microalgal biomass, the available literature is, at present, particularly scarce. Besides the need for the management of algal waste biomass and the energetic interest, the idea of domesticating the microbial loop that takes place in the natural environment (Caron, 1994), and thus the nitrogen and phosphorus recycling is the major issue that we address.

[R1Q3]

This paper reviews the potential of microalgae as a substrate for anaerobic digestion. First, the characteristics of microalgae regarding their biochemical composition are described and the theoretical methane yield is proposed, based on their gross composition. Secondly, experiments of anaerobic digestion of microalgae and the strategies to improve their conversion into methane are reported.

\section{Anaerobic digestion of microalgae}

\subsection{Microalgae composition}

Determining the composition of microalgae is a way to apprehend their digestion potential. The mineral composition of microalgae meets the nutrient requirements of the anaerobic microflora. Besides carbon, nitrogen and phosphorus which are major components in microalgae composition, oligo nutrients such as iron, cobalt, zinc are also found (Grobbelaar, 2004) and are known to stimulate methanogenesis (Speece, 1996).

These organisms have proportions of proteins (6-52\%), lipids (7-23\%) and carbohydrates (5-23\%) that are strongly species dependent (Brown et al., 1997). For several species the high proportion in proteins is caracterised by a low $\mathrm{C} / \mathrm{N}$ especially if compared with terrestrial plants. This ratio has an average of 10.2 for freshwater microalgae while it is 36 for terrestrial plants (Elser et al. 2000)[R2Q2]. Cell composition is also deeply affected by environmental conditions (Droop, 1983; Leadbeater, 2006). Variations in this composition may affect the performance of the anaerobic digestion.

\subsection{Theoretical approach of methane potential and ammonium release}

According to Angelidaki and Sanders (2004), when the composition of the organic matter is known, it is possible to evaluate the theoretical methane and ammonium yields that can be expected from the anaerobic digestion. These yields can be calculated with the following 
formula adapted from Symons and Buswell (1933). However, it must be kept in mind that this theoretical approach does not take into account needs for cell maintenance and anabolism.

$$
\mathrm{C}_{a} \mathrm{H}_{b} \mathrm{O}_{c} \mathrm{~N}_{d}+\left(\frac{4 a-b-2 c+3 d}{4}\right) \mathrm{H}_{2} \mathrm{O} \rightarrow\left(\frac{4 a+b-2 c-3 d}{8}\right) \mathrm{CH}_{4}+\left(\frac{4 a-b+2 c+3 d}{8}\right) \mathrm{CO}_{2}+d \mathrm{NH}_{3}
$$

In this equation, the organic matter is stoichiometrically converted to methane, carbon dioxide and ammonia.

The specific methane yield expressed in litres of $\mathrm{CH}_{4}$ per gram of Volatile Solids (VS) can thus be calculated as:

$$
B_{0}=\frac{4 a+b-2 c-3 d}{12 a+b+16 c+14 d} * V m
$$

where $\mathrm{Vm}$ is the normal molar volume of methane.

The ratio $r_{G}$ of methane to carbon dioxide can therefore be computed from $n=\frac{-b+2 c+3 d}{a}$, the average carbon oxidation state in the substrate (Harris and Adams, 1979), as follows:

$$
r_{G}=\frac{4-n}{4+n}
$$

The biogas composition however also depends on the amount of $\mathrm{CO}_{2}$ which is dissolved in the liquid phase through the carbonate system, and is therefore strongly related to $\mathrm{pH}$ [R2Q7].

The ammonium production yield in the digester can be evaluated using equation (1):

$$
\mathrm{Y}_{\mathrm{N}-\mathrm{NH} 3}\left(\mathrm{mg} \mathrm{gVS}^{-1}\right)=\frac{d * 17 * 1000}{12 a+b+16 c+14 d}
$$

Equation (1) is a theoretical approach that allows estimation of the maximum potential yields. However, as it will be discussed later on, if the cells are directly injected into the anaerobic process, the accessibility of the intracellular components is limited for some species by the specific nature of their cell wall (Becker, 1988). On the contrary, yield can be enhanced by cell disruption after extracting a specific sub-product such as lipids for biofuel (Chisti, 2007) and/or molecules of pharmaceutical interest (Spolaore et al., 2006). In this case, the remaining intracellular components become accessible for the anaerobic bacteria.

Table 1 (extracted from Angelidaki and Sanders (2004)) compiles specific methane yields for carbohydrates, lipids. For the specific case of proteins, the formula was calculated with the average composition in amino acids weighted by their frequency in Chlorella vulgaris (Becker 2007)[R2Q4]. In terms of theoretical methane potential, the higher the lipid content of the cell, the higher the potential methane yield. The high energetic content of lipids makes them attractive substrates for anaerobic digestion due to their higher gas production potential compared with carbohydrates and proteins (Cirne et al., 2007; Li et al., 2002). However, lipid hydrolysis is considered to be slower than protein and carbohydrate hydrolysis. Thus, Pavlostathis and Giraldo-Gomez (1991) calculated the minimum values of limiting generation time for anaerobic treatment of various substrates and they found values of $0.18,0.43$ and 3.2 days for carbohydrates, proteins and lipids respectively. Similar results are given by Christ et al. (1999) when estimating first-order hydrolysis constants for these substrates[R2Q3]. 
The raw estimate from Table 1 can be refined considering the organic composition of specific microalgae species. Using equation (1), it is possible to compute a theoretical specific methane yield associated to a theoretical ammonia release (Table 2). As expected, the species that can reach higher lipid content (e.g. Chlorella vulgaris) have a higher methane yield.

Obviously, in the case where lipids are extracted from algae before digestion, the potential methane yield is lower while the released ammonium is higher (See Table 4) [R1Q4].

\subsection{Operating conditions}

Compared to other organic substrates, studies dealing with anaerobic digestion of algae are scarce. Microalgae have received less attention than macroalgae as a substrate for anaerobic digestion. Two main approaches can be distinguished for unicellular algae. Either a multispecific biomass is harvested from a waste water treatment pond (Chen, 1987; Chen, 1998; Yen and Brune, 2007), or a monospecific biomass grown in the laboratory (Asinari Di San Marzano et al., 1982; Samson and LeDuy, 1982, 1986; Chen 1987; Sanchez and Travieso, 1993; Munoz et al., 2005). Table 3 summarizes the experimental conditions and the corresponding methane conversion yield for these reported studies. It shows that the methane yield varies from 0.09 to $0.45[\mathrm{R} 1 \mathrm{Q} 5] \mathrm{L}_{\mathrm{gVS}} \mathrm{gV}^{-1}$ depending on the species and culture conditions.

\subsubsection{Temperature effect}

The increase in temperature, from 15 to $52{ }^{\circ} \mathrm{C}$, improves the methane conversion of Spirulina maxima, and the productivity together with the volatile solids reduction is enhanced up to $35^{\circ} \mathrm{C}$ (Samson and LeDuy, 1986). For a multispecific[R1Q6] algal biomass, as studied by Golueke et al., (1957), a temperature increase from 35 to $50{ }^{\circ} \mathrm{C}$ can enhance the rate of algae biodegradability from 5 to 10 percent. The energetic balance is then negative if we consider the energy supplied for heating. However, mesophilic temperatures appear to be optimal conditions as confirmed by Chen (1987) who found a maximal methane productivity at $40^{\circ} \mathrm{C}$.

\subsubsection{Hydraulic retention time and loading rate}

The hydraulic and solid retention time (HRT and SRT) are key parameters in anaerobic processes. They should be high enough to allow the active populations to remain in the reactor, especially methanogens, and not to limit hydrolysis which is generally the limitingstep of the overall conversion of complex substrates to methane. In the case of slowly degradable complex organic pollutants, HRT is a deciding factor (Speece, 1996). When the process is operated at low loading rate and high hydraulic retention time, the methane yield[R1Q7] ( $\mathrm{L} \mathrm{CH}_{4} / \mathrm{gVS}$ fed) is constant and maximal. On the contrary when the maximal loading rate or minimum hydraulic retention time is reached, a decrease of the yield occurs.

For an efficient conversion of organic matter, optimal loading rates and hydraulic retention times must be chosen depending on the type or composition of the algal substrate. When the cells are directly injected into the anaerobic process, accessibility of the intracellular content to the anaerobic microflora is limited by the resistance of the algal cell wall to hydrolysis. Thus, characteristics of the species makes the difference for a given 
loading rate or hydraulic retention time as shown by Asinari Di San Marzano et al. (1982) and 236 Chen (1987) [R2Q6].

\subsubsection{Biogas quality}

The proportion of methane in the biogas produced is in a similar range (69 to $75 \%$ ) for

\section{Inhibitions induced by microalgae as substrate}

Two factors can have a significant impact on the methane yield and on productivity, inducing an inhibition of some of the anaerobic bacterial populations. On one hand, the high protein content of the algal biomass leads to a high ammonium release, thus inhibiting the anaerobic microflora. On the other hand, in the case of marine species, high sodium concentrations may alter the anaerobic process.

\subsection{Ammonium toxicity}

As described by Equation (1), and already discussed, the high nitrogen concentrations in the algae leads to a significant release of ammonia during fermentation. During anaerobic digestion, proteins are degraded and ammonia accumulates in the liquid phase. The $\mathrm{pH}$ value triggers the proportion between ammonium ions $\left(\mathrm{NH}_{4}{ }^{+}\right)$and free ammonia $\left(\mathrm{NH}_{3}\right)$. If the biomass concentration in the influent is high, this will cause high $\mathrm{NH}_{3}$ concentrations and alkalinity and, as a consequence, inhibition of the process by free ammonia may occur (McCarty, 1964). The unionized hydrophobic form of nitrogen diffuses passively across the cell membranes where it expresses its toxicity.

This phenomenon has been reported in many studies (Golueke et al., 1957; Eisenberg et al., 1981; Samson and LeDuy, 1982, 1983b, 1986; Chen, 1987). Anaerobic digestion of the protein rich cyanobacteria Spirulina maxima, containing up to $60 \%$ of proteins, releases a extremely high concentration of ammonia (up to $7000 \mathrm{mg} / \mathrm{L}$ ) (Samson and LeDuy, 1986). Two studies, Samson and LeDuy (1982) and Sanchez and Travieso (1993), observed a strong concentration of volatile fatty acids as a consequence of the toxic effect of ammonia on the anaerobic flora.

The acetoclastic methanogen bacteria are probably among the most sensitive to $\mathrm{NH}_{3}$ (Koster and Lettinga, 1984; Angelidaki and Ahring, 1993). Inhibiting concentrations vary in a wide range from 1.7 to $14 \mathrm{~g} \mathrm{~L}^{-1}$ and depend on several factors as the acclimation period, the nature of substrate and inoculum together with operating conditions (Angelidaki and Ahring, 1993). Thermophilic conditions enhance the inhibition effect. It can be related to the increase in free ammonia concentrations with increasing temperatures and thus with the process stability (Braun et al., 1981; Angelidaki and Ahring, 1994). High concentrations of ions such 
as $\mathrm{Na}^{+}, \mathrm{Ca}^{2+}, \mathrm{Mg}^{2+}$, which increase alkalinity and decrease the fraction of unionized $\mathrm{NH}_{3}$, can lower the inhibition effects (Chen et al., 2008).

It is worth noting that methanogenic bacteria can however acclimate to high concentrations of ammonium. Indeed, adaptation of the methanogenic ecosystem may increase the toxicity threshold level (Chen et al, 2008), even if the methane productivity remains low. For example, Koster and Lettinga (1988) reached a toxic threshold 6.2 times higher after an adaptation phase [R2Q8].

As a consequence of high ammonium concentrations, nitrogen can be found in the biogas in proportions correlated to the algal nitrogen content, as reported by Golueke et al. (1957). This phenomenon has been recently highlighted for more general nitrogen rich substrates (Strik et al., 2006).

\subsection{Sodium toxicity}

Sodium ions are required by the anaerobic microflora for its metabolism in a range from 0.002 to $0.004 \mathrm{M}$, but above $0.14 \mathrm{M}$, they become strongly inhibitory (Kugelman and McCarty, 1965; Mc Carty, 1964; Rinzema et al., 1988). Marine microalgae require a culture medium with high sodium chloride content $(0.5-1 \mathrm{M})$. Chen (1987) observed that the sodium chloride concentration has no particular effect up to $0.3 \mathrm{M}$. For $0.4 \mathrm{M}$ sodium chloride the methane production becomes affected and above $0.5 \mathrm{M}$ toxicity is reported.

However, it has been proved feasible to use salt-adapted micro-organisms capable of withstanding high salinities. The selection of salt-tolerant micro-organisms involves an adaptation of the sludge to high salt concentrations (Chen et al., 2008). Furthermore, the effluent organic loading rate and salt concentration should be equalised as far as possible, as these micro-organisms are sensitive to environmental shocks, especially in anaerobiosis (Lefebvre and Moletta, 2006). Hence, Aspé et al. (1997) adapted a marine inoculum to the treatment of a fishmeal industry effluent. This explains why no inhibiting effect occurred in some studies of saline waste anaerobic digestion for concentrations close to marine water (Asinari Di San Marzano et al., 1982; Omil et al., 1995) [R2Q9]. In mesophilic conditions the sodium turns out to be less inhibitory than in thermophilic conditions (Chen et al., 2008). The presence of other ions $\left(\mathrm{Ca}^{2+}, \mathrm{K}^{+}, \mathrm{Mg}^{2+}\right)$ can also play a significant, antagonistic or synergistic role, on the potential toxicity of sodium (Chen et al., 2008).

\section{Anaerobic digestion enhancement}

The composition of the organic substrates is one of the most important factors determining the methane conversion yield (Chynoweth and Isaacson, 1987). However, if the algal biomass does not result from any cell disruption process, the cell walls could strongly modulate this aspect by protecting the cell against the enzymes produced by the anaerobic consortium, and thus reducing the cell biodegradability[R1Q8]. Indeed, some microalgae species can be very resistant to hydrolysis, which drastically reduces their anaerobic biodegradability (Golueke et al., 1957; Uziel, 1978; Sanchez and Travieso, 1993). During their experiments (Golueke et al., 1957) identified intact cells in the digester and Uziel (1978) reported the same observation even after 30 days. Sanchez and Travieso (1993) observed that the chlorophyll concentration increased in the digester during the first two weeks of the experiment, and was still detected after 64 days; the presence of oxygen in the biogas was also reported as a consequence of the photosynthetic activity from the recalcitrant cells. For example, Scenedesmus $s p$ and Chlorella $s p$ are known to have a recalcitrant cellulosic cell wall (Okuda 2002).

Pre-treatment can be successfully applied in order to lower the recalcitrant organic fraction and thus increase the methane conversion (Tsao, 1987). 
Pretreatment of a substrate prior to anaerobic digestion allows to significantly improve its biodegradability while acting on its physico-chemical properties: this step makes the organic matter more accessible to the anaerobic microflora and thus more easily degraded.

One generally distinguishes physical and chemical pretreatment processes. Separation techniques, concentration or dehydration, mobilize and maximize the proportion of organic matter in the fraction to be digested (Angelidaki and Ahring, 2000). Chemical treatments (acids, bases, ozonation), thermal treatment and ultrasonic lysis improve the disintegration of the most refractory organic fractions (Bonmati et al., 2001; Bougrier et al., 2006). These operations increase kinetics of production and/or methane yield.

Ultrasonic pretreatment can enhance the crude protein digestibility, as shown with experiments on the digestibility of Chlorella vulgaris in rats (Janczyk et al., 2007). The same effect has been observed with high pressure homogenization (Komaki et al., 1998). These techniques have turned out to be efficient means for improving the methane conversion yields (Samson and Leduy, 1983a; Chen and Oswald, 1998).

Chen and Oswald (1998) studied different pretreatments for an algal biomass produced in sewage treatment ponds. The effect of temperature, duration of the treatment, substrate concentration and sodium hydroxide addition were investigated. These pretreatments enhanced the methane specific gas production. The temperature appeared to have the most important effect, and the optimal pretreatment consisted in heating at $100{ }^{\circ} \mathrm{C}$ during $8 \mathrm{~h}$ resulting in a $33 \%$ improvement of methane production. Samson and Leduy (1983a) obtained the best performance for Spirulina maxima with a thermal pretreatment at $150{ }^{\circ} \mathrm{C}$ and a $\mathrm{pH}=11$. The example of a full-scale plant for the thermal hydrolysis of sewage sludge reported by (Kepp et al., 2000), demonstrates that the improvement of the methane yield can energetically balance the thermal pretreatment.

\subsection{Increasing the theoretical methane potential: a metabolic approach}

The variation in the composition of microalgae is directly influenced by their growth conditions (Qiang, 2004; Spoehr and Milner, 1949). Most microalgae have the capacity, under certain conditions, to accumulate important quantities of carbon in the form of starch or lipids (Qiang, 2004). This capacity of accumulation, especially for lipids, has stimulated research aiming at the production of lipid biofuel (Chisti, 2007). The nitrogen deficiency is a well known condition to stimulate this accumulation (Ketchum and Redfield, 1949). Illman et al. (2000) evaluated the calorific value of five different species of Chlorella grown under low nitrogen concentrations and showed that the calorific value was directly correlated with the lipid content. The protein content was significantly reduced (Table 4) and the lipid accumulation resulted in a significant increase in the calorific value of the biomass.

A nitrogen limitation leads to an increase in the concentration of intracellular lipids (Table 4), but also to a reduction in the growth rate. From equation (2) and (4), it is possible to calculate the effect of nitrogen limitation on the cell stoichiometry, and thus on the theoretical methane potential and the theoretical ammonia release (Table 2). It is worth underlining that nitrogen limited cells have a lower protein content which leads to a lower release of ammonia. These two phenomena may therefore improve both the conversion efficiency and the stability of the process by limiting the toxic effect of ammonia.

When the anaerobic process is dedicated to digestion of cell residues after lipid extraction, biodiesel and methane are recovered, thus strongly increasing the energetic productivity of the microalgal culture (see Table 5). As mentioned by Chisti (2008), the anaerobic production of methane with cell residues is a key issue to balance both energetic and economic aspects. However, in this case the fraction of energy recovered under the form 
of methane is reduced (theoretical methane potential is decreased) and the ammonium release increased. The high ammonium concentration may then strongly limit and even jeopardize the process stability. To manage this rich nitrogen substrate, a codigestion with a poor nitrogen substrate is thus necessary.

\subsection{Codigestion}

The association of various substrates is a strategy to increase the performance of a digester by ensuring an optimal influent composition. It has been shown to strongly enhance the biogas productivity (Mata-Alvarez et al., 2000). When $\mathrm{C} / \mathrm{N}$ is lower than 20 [R3Q8], there is an imbalance between carbon and nitrogen requirements for the anaerobic microflora (Speece 1996) leading to nitrogen release, which can become inhibiting and results in an accumulation of volatile fatty acids.

Yen and Brune (2007) reported a significant enhancement of the methane production with an addition of waste paper to algal sludge feedstock, the optimum $\mathrm{C} / \mathrm{N}$ was observed to be between 20 and 25 . In mesophilic conditions, for a 10-days retention time and a loading rate at $4 \mathrm{~g} \mathrm{VS} \mathrm{L}^{-1} \cdot \mathrm{d}^{-1}$, the blend with $50 \%$ waste paper based on volatile solids concentration doubles the methane production rate compared to direct anaerobic digestion of algal biomass $\left(1.17 \mathrm{~L} \mathrm{~L} \mathrm{~L}^{-1} \mathrm{~d}^{-1}\right.$ vs. $\left.0.57 \mathrm{~L} \mathrm{~L}^{-1} \mathrm{~d}^{-1}\right)$. In the same conditions, with a loading rate of $5 \mathrm{gVS} \mathrm{L}^{-1} \mathrm{~d}^{-1}$, the algal sludge mixed with $60 \%$ of waste paper, lead to a maximum methane production rate of 1.61 L L $\mathrm{L}^{-1}$ [R1Q10].

The improved performance with such an approach are confirmed by Chen (1987) who associated algae with effluent from canning facility and protein-extracted algae. In this case the optimal methane specific gas production was reached for a $\mathrm{C} / \mathrm{N}$ ratio between 25 and 35 . In these studies, the optimal $\mathrm{C} / \mathrm{N}$ ratio was found between 20 and 35 . This value is close to the described range known to have a positive effect on the methane yield (Angelidaki et al., 2003). Lower ratios lead to potential inhibition due to the presence of free ammonia whereas higher ratios may lead to potential nitrogen limitations. By increasing the $\mathrm{C} / \mathrm{N}$ ratio (from 4.2 to 6.2) using sewage sludge, Samson and LeDuy (1983b) enhanced both methane yield and productivity during the codigestion of Spirulina maxima. Some co-substrate can have a coeffect in the sense that they stimulate enzymatic synthesis that can also improve the anaerobic digestion yield [R3Q9]. Indeed, Yen and Brune (2007) showed an increase in the cellulase activity stimulated by the specific nature of the waste paper. It probably had a positive effect on the digestion of algal cell walls and therefore on the anaerobic digestion itself. Finally, codigestion leads to the dilution of certain toxic compounds maintaining them under their toxic threshold.

\section{Biogas purification[R2Q13] [R3Q4]}

Autotrophic photosynthesis of microalgae supposes a continuous $\mathrm{CO}_{2}$ consumption during the light phase. This property advantageously points to these fast-growing organisms as a promising technology for $\mathrm{CO}_{2}$ fixation [R2Q13][R3Q4] (Li, 2008; Wang, 2008)[R3Q5]. In the 60s, Oswald and Golueke (1960) demonstrated the feasibility of mitigating gas effluents resulting from a power plant with a high-rate pond. Furthermore, the addition of $\mathrm{CO}_{2}$ in algal ponds enhances algal growth (Olaizola, 2003; Doucha et al., 2005) provided that $\mathrm{pH}$ is regulated. It also maintains a low $\mathrm{pH}$ that decreases the gaseous ammonia emission (Heubeck et al., 2007). The $\mathrm{CO}_{2}$ concentration in a biogas in the range 30 to $50 \%$ appears to be compatible with the toxicity and inhibition thresholds reported for the commonly exploited species (Maeda et al., 1995). 
The filtration of the biogas by algal cultures supplies $\mathrm{CO}_{2}$ to the culture, thus enhancing

\section{Is it worth to recover lipids from an energetic point of view?}

In this section we provide several elements in order to compare the direct strategy (methanizing the whole biomass) and the indirect one, including lipid recovery and methane production with the algal wate. Table 5 highlights the comparison between these two scenarii. For an algal lipid content lower than $40 \%$, the energetic added value when recovering lipids is lower than $21 \%$ of the recovered energy. However, the energetic cost of biomass harvesting and lipid recovery is probably higher than $30 \%$ of the recovered energy, especially since most of the existing techniques involve biomass drying (Carlsson et al., 2007), while the direct strategy would involve only a sedimentation and preconcentration stage in a settler. This put an emphasis on the idea that direct energy recovery can be of interest in the case where the lipid content is lower than $40 \%$. This point is consolidated when considering the triacylglycerols which are the actual substrate to produce biodiesel. They may represent only a small fraction of total lipids when no nitrogen limitation is induced, and thus in the situations when lipid content is low (Rodolfi et al. 2008). This assumption is further confirmed when the productivity is taken into account. A nitrogen limitation induces a strong 
decrease in growth rate (Droop, 1983). Consequently the increase in the lipid content is generally not compensated and eventually productivity is decreased (Rodolfi et al. 2008). Hence, even the energetic advantage for the indirect scenario appearing in Table 5 for algal lipid contents higher than $40 \%$ could be strongly reduced due to a decrease in productivity.[R2Q11] [R3Q1] [R2Q3]

\section{Conclusion}

The perspective of large scale microalgae production for $\mathrm{CO}_{2}$ fixation and/or lipid fuel production assumes large amounts of fertilizers, especially if compared to terrestrial plants. Nitrogen and phosphorus remineralisation using anaerobic digestion can support this strong nutrient requirement and moreover recover additional energy through methane. However this operation is not straightforward and three main aspects have to be considered:

1 - In the case of marine algae, sodium can inhibit anaerobic digestion. However this issue has already been addressed and adapted bacteria seem to be efficient.

2- The release of nitrogen is toxic at high concentrations. This effect should be exacerbated if $\mathrm{pH}$ increases. To control and limit the risk of destabilizing the anaerobic process by free ammonia, several strategies have been investigated. A microalgae codigestion with a nitrogen poor substrate can be an answer to this problem. The second answer would be to use species with a higher $\mathrm{C} / \mathrm{N}$ ratio, and to apply culture conditions that maximise this ratio. However the strategy needs to be adapted, depending whether lipids have been recovered in a preliminary step.

3 - If the cell lipid content does not exceed $40 \%$, the anaerobic process appears to be the optimal strategy on an energy balance basis, for the energetic recovery of cell biomass.

This study justifies the exploration of the potential of the direct scenario, without lipid recovery, and provides new motivations to more accurately identify the lipid content threshold under which recovering the oil is no more relevant from an energetic point of view.

Explored about fifty years ago, the promising integration process coupling anaerobic digestion and microalgal culture deserves sustained research and development efforts and will probably re-emerge in the coming years either as a mandatory step to support large scale microalgal cultures or as a stand alone bioenergy producing process.[R2Q15] [R3Q3]

\section{Acknowledgements}

This work benefited from the support of the Shamash and Symbiose research projects founded by the French National Research Agency (ANR). Special thanks to J.P. Steyer for his advice and J. \&M. Ras for improving the English.

\section{References}

Afi L, Metzger P, Largeau C, Connan J, Berkaloff C, Rousseau B. Bacterial degradation of green microalgae: incubation of Chlorella emersonii and Chlorella vulgaris with Pseudomonas oleovorans and Flavobacterium aquatile. Proceedings of the 17th International Meeting on Organic Geochemistry 1996;25(1-2):117-130.

Angelidaki I, Ahring BK. Thermophilic anaerobic digestion of livestock waste : the effect of ammonia. Appl. Microbiol. Biotechnol. 1993; 38:560-564. 
Angelidaki I, Ahring BK. Anaerobic thermophilic digestion of manure at different ammonia loads: effect of temperature. Water Res. 1994; 28:727-731.

Angelidaki I, Ahring BK. Methods for increasing the biogas potential from the recalcitrant organic matter contained in manure. Water Sci. Technol. 2000; 41(3):189-194.

Angelidaki I, Ellegaard L, Ahring BK. Applications of the anaerobic digestion process. In: Ahring BK, editor. Biomethanation, Springer Berlin / Heidelberg, 2003. p.1-33.

Angelidaki I, Sanders W. Assessment of the anaerobic biodegradability of macropollutants. Rev. Environ. Sci. Biotechnol. 2004;3:117-129.

Asinari Di San Marzano CM, Legros A, Naveau HP, Nyns EJ. Biomethanation of the marine algae Tetraselmis. Int. J. Sustain. Energy. 1982;1:263-272.

Aspé E, Marti MC, Roeckel M. Anaerobic treatment of fishery wastewater using a marine sediment inoculum. Water Res. 1997:31:2147-2160.

Becker EW. Micro-algae for human and animal consumption. In: Borowitzka MA and Borowitzka LJ, editors. Micro-algal technology, Cambridge University Press, 1988. p.222-256.

Becker EW. Microalgae in human and animal nutrition. In: Richmond A, editor. Handbook of microalgal culture. Blackwell Publishing Oxford, 2004. p.312-351.

Becker EW. Micro-algae as a source of protein. Biotechnol. Adv. 2007;25:207-210.

Bonmati A, Flotats X, Mateu L, Campos E. Study of thermal hydrolysis as a pretreatment to mesophilic anaerobic digestion of pig slurry. Water Sci. Technol. 2001;44(4):109-116.

Bougrier C, Albasi C, Delgenès JP, Carrère H. Effect of ultrasonic, thermal and ozone pretreatments on waste activated sludge solubilisation and anaerobic biodegradability. Chem. Eng. Proc. 2006;45:711-718.

Braun R, Huber P, Meyrath J. Ammonia toxicity in liquid piggery manure digestion. Biotechnol. Lett. 1981;3:159-164.

Brown MR, Jeffrey SW, Volkman JK, Dunstan GA. Nutritional properties of microalgae for mariculture. Aquaculture. 1997;151:315-331.

Caron DA, Inorganic nutrients, bacteria, and the microbial loop. Microbial Ecol. 1994:28: 295-298

Carlsson AS,. Van Bilein JB, Möller R, Clayton D, Bowles D, Outputs from EPOBIO Project :Micro-and Macroalgae utility for industrial application, CPL Press, York, UK, Sept. 2007

Chae SR, Hwang EJ, Shin HS. Single cell protein production of Euglena gracilis and carbon dioxide fixation in an innovative photo-bioreactor. Bioresour. Technol. 2006;97:322329.

Chen PH. Factors influencing methane fermentation of micro-algae. $\mathrm{PhD}$ thesis, University of California, Berkeley, CA, USA, 1987.

Chen $\mathrm{PH}$, Oswald WJ Thermochemical treatment for algal fermentation. Environ. Int. 1998;24:889-897.

Chen Y, Cheng JJ, Creamer KS. Inhibition of anaerobic digestion process: A review. Bioresour. Technol. 2008; 99:4044-4064.

Chisti Y. Biodiesel from microalgae. Biotechnol. Adv. 2007; 25: 294-306.

Chisti Y. Biodiesel from microalgae beats bioethanol. Trends Biotechnol. 2008.26: 126-131.

Christ O, Wilderer PA, Angerhöfer R, Faulstich M. Mathematical modeling of the hydrolysis of anaerobic processes. Water Sci. Technol. 2000;41(3):61-65.

Chynoweth DP, Isaacson R. Anaerobic digestion of biomass. Elsevier Applied Science Publishers LTD, 1987.

Cirne DG, Paloumet X, Björnsson L, Alves MM, Mattiasson B. Anaerobic digestion of lipidrich waste--Effects of lipid concentration. Renew. Energy. 2007 ;32:965-975. 
Derenne S, Largeau C, Berkaloff C, Rousseau B, Wilhelm C, Hatcher PG. Non-hydrolysable macromolecular constituents from outer walls of Chlorella fusca and Nanochlorum eucaryotum. Phytochemistry. 1992;31:1923-1929.

Doucha J, Straka F, Livansky K. Utilization of flue gas for cultivation of microalgae (Chlorella sp.) in an outdoor open thin-layer photobioreactor. J. Appl. Phycol. 2005; 17:403-412.

Droop MR, 25 years of algal growth kinetics. Botanica marina.1983:26:99-112

Eisenberg DM, Benemann JR, Weissman JC, Oswald WJ. Large-scale freshwater microalgae biomass production for fuel and fertilizer, Final Report. Golden, Colorado, Solar Energy Research Institute, 1981.

Elser, J.J., Fagan, W.F., Denno, R.F., Dobberfuhl, D.R., Folarin, A., Huberty, A., Interlandi, S., Kilham, S.S., McCauley, E., Schulz, K.L., Siemann, E.H. \& Sterner, R.W. . Nutritional constraints in terrestrial and freshwater food webs. Nature, 2000; 408: 578580.

Goldman JC, Caron DA, Dennett MR. Regulation of gross coefficient efficiency and ammonium regeneration in bacteria by substrate $\mathrm{C}: \mathrm{N}$ ratio. Limnol. Oceanography, $1987 ; 32: 1239-1252$.

Golueke CG, Oswald WJ, Gotaas HB. Anaerobic digestion of algae. Appl. Microbiol. 1957;5:47-55.

Grobbelaar JU. Algal Nutrition. In Richmond A, editor. Handbook of microalgal culture: biotechnology and applied phycology, Wiley-Blackwell, 2004.

Halleux H.,Lassaux S.,Renzoni R.,Germain A., Comparative life cycle assessment of two biofuels ethanol from sugar beet and rapeseed methyl ester. Int. J. LCA.2008:13(3):184-190.

Harris RF Adams SS. Determination of the carbon-bound electron electron composition of microbial cells and metabolites by dichromate oxidation. Appl. Environ. Microbiol.1979:37:237-243.

Heubeck S, Craggs RJ, Shilton A. Influence of $\mathrm{CO}_{2}$ scrubbing from biogas on the treatment performance of a high rate algal pond. Water Sci. Technol. 2007; 55(11):193-200.

Huntley ME, Redalje DG . $\mathrm{CO}_{2}$ mitigation and renewable oil from photosynthetic microbes: a new appraisal. Mitig Adapt Strategies Glob Chang. 2007; 12:573-608.

Illman A, Scragg A, Shales S. Increase in Chlorella strains calorific values when grown in low nitrogen medium. Enzyme Microb. Technol. 2000; 27:631-635.

Janczyk P, Franke H, Souffrant WB. Nutritional value of Chlorella vulgaris: Effects of ultrasonication and electroporation on digestibility in rats. Animal Feed Sci. Technol. 2007;132:163-169.

Kepp U, Machenbach I, Weisz N, Solheim OE. Enhanced stabilisation of sewage sludge through thermal hydrolysis - three years of experience with full scale plant. Water Sci. Technol. 2000; 42(9):89-96.

Ketchum BH, Redfield, AC. Some physical and chemical characteristics of algae growth in mass culture. J. Cell Physiol. 1949;33:281-99.

Komaki H, Yamashita M, Niwa Y, Tanaka Y, Kamiya N, Ando Y et al. The effect of processing of Chlorella vulgaris: K-5 on in vitro and in vivo digestibility in rats. Animal Feed Sci. Technol. 1998; 70:363-366.

Koster IW, Lettinga G. The influence of ammonium-nitrogen on the specific activity of pellitized methanogenic sludge. Agric. Wastes. 1984; 9:205-216.

Koster IW, Lettinga G. Anaerobic digestion at extreme ammonia concentrations. Biol. Wastes 1988;25:51-59.

Kugelman IJ, McCarty PL. Cation toxicity and stimulation in anaerobic waste treatment. I. Slug feed studies. J. Water Pollut. Control. Fed. 1965; 37:97-116. 
661

662

663

664

665

666

667

668

669

670

671

672

Labeckas G., Slavinskas S., Comparative performance of direct injection diesel engine operating on ethanol, petrol and rapeseed oil blends. 2009. Ener. Conv. Manag.; 50(3):792-801.

Leadbeater, BSC, The 'Droop Equation'-Michael Droop and the Legacy of the 'Cell-Quota Model' of Phytoplankton Growth. Protist. 2006, 157(3):345-358.

Lefebvre O, Moletta R. Treatment of organic pollution in industrial saline wastewater: A literature review. Water Res. 200; 40:3671-3682.

Li Y., Horsman M., Wu N., Lan C.Q., Dubois-Calero N. Biofuels from microalgae. Biotech. Prog. 2008; 24(4):815-820.

Li YY, Sasaki H, Yamashita K, Seki K, Kamigochi I. High-rate methane fermentation of lipid-rich food wastes by a high-solids co-digestion process. Water Sci. Technol. 2002; 45(12):143-150.

Maeda K, Owada M, Kimura N, Omata K, Karube $\mathrm{I}_{\text {. }} \mathrm{CO}_{2}$ fixation from the flue gas on coalfired thermal power plant by microalgae. Energy Conv. Manag. 1995;36:717-720.

Mandeno G, Craggs R, Tanner C, Suskias J, Webster-Brown J. Potential biogas scrubbing using a high rate pond. Water Sci. Technol. 2005;51(12):253-256.

Mata-Alvarez J, Macé S, Llabrés P. Anaerobic digestion of organic solid wastes. An overview of research achievements and perspectives. Bioresour. Technol. 2000; 74:3-16.

Mc Carty PL. Anaerobic waste treatment fundamentals. Public Works. 1964; 95(9): 91-99.

Metting FB. Biodiversity and application of microalgae. J. Ind. Microbiol. 1996; 17:477-89.

Michiki $\mathrm{H}$. Biological $\mathrm{CO}_{2}$ fixation and utilization project. Energy Conv. Manag. 1995:36:701-705.

Munoz R, Jacinto M, Guieysse B, Mattiasson B. Combined carbon and nitrogen removal from acetonitrile using algal-bacterial bioreactors. Appl. Microbiol. Biotechnol. 2005; 67:699-707.

Okuda K. Structure and phylogeny of cell coverings. J. Plant Res. 2002;115:283-288.

Olaizola M. Commercial development of microalgal biotechnology: from the test tube to the marketplace. Biomol. Eng. 2003; 20:459-466.

Olguín E.J., The cleaner production strategy applied to animal production. In: E.J. Olguín, G. Sánchez and E. Hernández, Editors, Environmental biotechnology an cleaner bioprocesses, Taylor and Francis, London (2000), pp. 227-243.

Omil F, Mendez R, Lema JM. Anaerobic treatment of saline wastewaters under high sulfide and ammonia content. Bioresour. Technol. 1995; 54:269-278.

Oswald WJ, Golueke CG. Biological transformation of solar energy. Adv. Appl. Microbiol. 1960; 2:223-262.

Pavlostathis SG, Giraldo-Gomez E. Kinetics of anaerobic treatment: A critical review. CRC Crit. Rev. Environ. Control. 1991:21:411-490.

Phang S.M., Miah M.S., Yeoh B.G., Hashim M.A. Spirulina cultivation in digested sago starch factory wastewate. J. Appl. Phyco.2000; 12(3):395-400.

Qiang H. Environmental effects on cell composition. In Richmond A, editor. Handbook of microalgal culture: biotechnology and applied phycology, Wiley-Blackwell, 2004. p. 83-93.

Rasi S, Veijanen A, Rintala J. Trace compounds of biogas from different biogas production plants. Energy. 2007; 32: 1375-1380.

Rathke G.-W., Behrens T., Diepenbrock W., Integrated nitrogen management strategies to improve seed yield, oil content and nitrogen efficiency of winter oilseed rape (Brassica napus L.): A review. Agric. Ecosyst. Environ. 2006;17(2-3): 80-108.

Rinzema A, van Lier, J., Lettinga G. Sodium inhibition of acetoclastic methanogens in granular sludge from a UASB reactor. Enzyme Microb. Technol. 1988;10:24-32. 
Rodolfi L., Chini Zittelli G., Bassi N., Padovani G., Biondi N., Bonini G., Tredici M.R. Microalgae for oil: Strain selection, induction of lipid synthesis and outdoor mass cultivation in a low-cost photobioreactor. 2009. Biotech. Bioeng; 102(1): 100-112.

Samson R, LeDuy A. Biogas production from anaerobic digestion of Spirulina maxima algal biomass. Biotechnol. Bioeng. 1982;24:1919-1924.

Samson R, LeDuy A. Influence of mechanical and thermochemical pretreatments on anaerobic digestion of Spirulina maxima algal biomass. Biotechnol. Lett. 1983a; 5:671-676.

Samson R, LeDuy A. Improved performance of anaerobic digestion of Spirulina maxima algal biomass by addition of carbon-rich wastes. Biotechnol. Lett. 1983b; 5:677-682.

Samson R, LeDuy A. Detailed study of anaerobic digestion of Spirulina maxima algae biomass. Biotechnol. Bioeng. 1986;28:1014-1023.

Sanchez EP, Travieso L. Anaerobic digestion of Chlorella vulgaris for enrgy production." Resour, Conserv. Recycl. 1993; 9:127-132.

Speece RE Anaerobic biotechnology for industrial wastewaters. Nashville, Archae press. 1996.

Spoalore P, Joannis-Cassan C, Duran E, Isambert A. Commercial application of microalgae. J. Biosci. Bioeng. 2006; 101:87-96.

Spoehr HA, Milner HW. The chemical composition of Chlorella; effect of environmental conditions. Plant Physiol. 1949:24:120-49.

Strik D, Domnanovich AM, Holubar P. A pH-based control of ammonia in biogas during anaerobic digestion of artificial pig manure and maize silage. Proc. Biochem. 2006; 41:1235-1238.

Symons GE, Buswell AM. The methane fermentation of carbohydrates. J. Am. Chem. Soc. 1933 55: 2028-2036.

Travieso L, Sanchez EP, Benitez F, Conde JL. Arthospira sp. intensive cultures for food and biogas purification. Biotechnol. Lett. 1993; 15:1091-1094.

Tsao GT. Pre-/Postreatment. Anaerobic digestion of biomass. D. P. Chynoweth and R. Isaacson, Elsevier Applied Science, 1987.

Uziel M. Solar energy fixation and conversion with algal bacterial systems. PhD thesis. University of California, Berkeley, CA, USA, 1978

Vandenbroucke M, Largeau C. Kerogen origin, evolution and structure. Org. Geochem. 2007; 38:719-833.

Wang B., Li Y., Wu N., Lan C.Q. $\mathrm{CO}_{2}$ bio-mitigation using microalgae. Appl Microbiol. and Biotechnol. 2008; 79(5): 707-718

Yen HW, Brune DE. Anaerobic co-digestion of algal sludge and waste paper to produce methane. Bioresour. Technol. 2007; 98: 130-134. 
Table 1

712 Specific methane yield for three types of organic compounds

713

714

715

716

717

718

719

720

721

722

723

724

\begin{tabular}{lll}
\hline Substrate & Composition & $\mathbf{L ~ C H}_{\mathbf{4}} \mathbf{g ~ V S}^{\mathbf{1}}$ \\
\hline Proteins & $\mathrm{C}_{6} \mathrm{H}_{13.1} \mathrm{O}_{1} \mathrm{~N}_{0.6}$ & 0.851 \\
Lipids & $\mathrm{C}_{57} \mathrm{H}_{104} \mathrm{O}_{6}$ & 1.014 \\
Carbohydrates & $\left(\mathrm{C}_{6} \mathrm{H}_{10} \mathrm{O}_{5}\right) \mathrm{n}$ & 0.415 \\
\hline
\end{tabular}

\section{Table 2}

Gross composition of several microalgae species (Becker, 2004) and calculated (using equation (1)) theoretical methane potential and theoretical ammonia release during the anaerobic digestion of the total biomass

\begin{tabular}{|c|c|c|c|c|c|}
\hline Species & $\begin{array}{l}\text { Proteins } \\
(\%)\end{array}$ & $\begin{array}{l}\text { Lipids } \\
\text { (\%) }\end{array}$ & $\begin{array}{c}\text { Carbohydrates } \\
(\%)\end{array}$ & $\begin{array}{c}\mathbf{C H}_{4}[\mathrm{R} 1 \mathrm{Q} 12] \\
\left(\mathbf{L} \mathbf{C H}_{4} \mathrm{~g} \mathrm{VS}^{-1}\right)\end{array}$ & $\begin{array}{c}\mathrm{N}-\mathrm{NH}_{3} \\
\left(\mathrm{mg} \mathrm{gVS}^{-1}\right)\end{array}$ \\
\hline Euglena gracilis & $39-61$ & $14-20[\mathrm{R} 2 \mathrm{Q} 5]$ & $14-18$ & $0.53-0.8$ & $54.3-84.9$ \\
\hline \multicolumn{6}{|l|}{ Chlamydomonas } \\
\hline reinhardtii & 48 & 21 & 17 & 0.69 & 44.7 \\
\hline Chlorella pyrenoidosa & 57 & 2 & 26 & 0.8 & 53.1 \\
\hline Chlorella vulgaris & $51-58$ & $14-22$ & $12-17$ & $0.63-0.79$ & $47.5-54.0-$ \\
\hline Dunaliella salina & 57 & 6 & 32 & 0.68 & 53.1 \\
\hline Spirulina maxima & $60-71$ & $6-7$ & $13-16$ & $0.63-0.74$ & $55.9-66.1$ \\
\hline Spirulina platensis & $46-63$ & $4-9$ & $8-14$ & $0.47-0.69$ & $42.8-58.7$ \\
\hline Scenedesmus obliquus & $50-56$ & $12-14$ & $10-17$ & $0.59-0.69$ & $46.6-42.2$ \\
\hline
\end{tabular}


Table 3

728 Experiments with anaerobic digestion of microalgae species and algal sludge: substrate

729 characteristics, methane yield [R1Q14] and process conditions

\begin{tabular}{|c|c|c|c|c|c|c|c|}
\hline Reactor & Substrate & $\begin{array}{c}\mathbf{T}^{\mathrm{a}} \\
\left({ }^{\circ} \mathrm{C}\right)\end{array}$ & $\begin{array}{l}\text { HRT }^{\text {d }} \\
\text { (d) }\end{array}$ & $\begin{array}{l}\text { Loading rate } \\
\left(\text { gVS. } L^{-1} \cdot j^{-1}\right)\end{array}$ & $\begin{array}{c}\text { Methane yield } \\
{[\mathrm{R} 1 \mathrm{Q} 14]} \\
\left(\mathbf{L} \mathbf{C H}_{4} \mathbf{g ~ V S}^{-1}\right) \\
\end{array}$ & $\begin{array}{c}\mathrm{CH}_{4} \\
\text { (\% vol) }\end{array}$ & References \\
\hline \multirow[t]{4}{*}{ Batch $11 \mathrm{~L}$} & $\begin{array}{l}\text { Algae sludge } \\
\text { (Chlorella-Scenedesmus) }\end{array}$ & $35-50$ & $3-30$ & $1.44-2.89$ & $0.17-0.32$ & $62-64$ & (Golueke et al., 1957) \\
\hline & Algal biomass & 35 & 28 & 1 & 0.42 & 72 & \multirow{3}{*}{ (Chen, 1987) } \\
\hline & Spirulina & 35 & 28 & 0.91 & $0.32-0.31$ & & \\
\hline & Dunaliella & 35 & 28 & 0.91 & $0.44-0.45$ & & \\
\hline \multirow{3}{*}{$\operatorname{CSTR}^{\mathrm{b}} 2-5 \mathrm{~L}$} & Tretraselmis (fresh) & 35 & 14 & 2 & 0.31 & $72-74$ & \multirow{3}{*}{$\begin{array}{c}\text { (Asinari Di San Marzano } \\
\text { et al., 1982) }\end{array}$} \\
\hline & Tretraselmis (dry) & 35 & 14 & 2 & 0.26 & $72-74$ & \\
\hline & $\begin{array}{l}\text { Tretraselmis (dry) } \\
+\mathrm{NaCl} 35 \mathrm{~g} / \mathrm{L}\end{array}$ & 35 & 14 & 2 & 0.25 & $72-74$ & \\
\hline Batch $5 \mathrm{~L}$ & Chlorella vulgaris & $28-31$ & 64 & - & $0.31-0.35^{\mathrm{d}}$ & $68-75$ & (Sanchez and Travieso, 1993) \\
\hline $\begin{array}{l}\text { Semi } \\
\text { continuous } \\
\text { (daily fed) } 10 \mathrm{~L}\end{array}$ & Spirulina maxima & 35 & 33 & 0.97 & 0.26 & $68-72$ & (Samson and LeDuy, 1982) \\
\hline Fed Batch $2 \mathrm{~L}$ & Spirulina maxima & $15-52$ & $5-40$ & $20-100$ & $0.25-0.34$ & $46-76$ & (Samson and LeDuy, 1986) \\
\hline $\operatorname{CSTR}^{\mathrm{b}} 4 \mathrm{~L}$ & Chlorella-Scenesmus & 35 & 10 & $2-6$ & $0.09-0.136$ & 69 & (Yen and Brune, 2007) \\
\hline
\end{tabular}

$730 \quad{ }^{a}$ Temperature

${ }^{\mathrm{b}}$ Continuous Stirred-Tank Reactor

${ }^{c}$ estimated from data given in L CH4.gCOD-1 using a COD/VS ratio of 1.5 (where COD is the Chemical Oxygen Demand)

${ }^{\mathrm{d}}$ Hydraulic Retention Time

734 [R1Q13] 
Table 4

738 Effect of low nitrogen growth conditions on the composition of five Chlorella species and estimation of the theoretical methane potential and theoretical ammonia release (in brackets: computed theoretical methane potential and ammonia release of the residual biomass after lipid extraction).

742

\begin{tabular}{lccccccccc}
\hline Species & $\begin{array}{c}\text { Growth } \\
\text { conditions }\end{array}$ & $\begin{array}{c}\text { Proteins } \\
(\mathbf{\%})\end{array}$ & $\begin{array}{c}\text { Lipids } \\
(\mathbf{\%})\end{array}$ & $\begin{array}{c}\text { Carbohydrates } \\
(\mathbf{\%})\end{array}$ & $\begin{array}{c}\text { Calorific value } \\
(\mathrm{Kj} / \mathrm{g})\end{array}$ & $\begin{array}{c}\mathrm{CH}_{4} \\
\left(1 \mathrm{CH}_{4} \mathrm{~g} \mathrm{VS}^{-1}\right)\end{array}$ & $\begin{array}{c}\mathbf{N}^{-N_{3}} \\
\left(\mathrm{mg} \mathrm{gVS}^{-1}\right)\end{array}$ \\
\hline C.vulgaris & - & 29 & 18 & 51 & 18 & 0.64 & $(0.56)$ & 27.0 & $(32.9)$ \\
C.vulgaris & Low N & 7 & 40 & 55 & 23 & 0.69 & $(0.48)$ & 6.5 & $(10.9)$ \\
C.emersonii & - & 32 & 29 & 41 & 21 & 0.74 & $(0.62)$ & 29.8 & $(42.0)$ \\
C.emersonii & Low N & 28 & 63 & 11 & 29 & 0.92 & $(0.76)$ & 26.1 & $(70.5)$ \\
C.protothecoides & - & 38 & 11 & 52 & 19 & 0.65 & $(0.60)$ & 34.5 & $(39.8)$ \\
C.protothecoides & Low N & 36 & 23 & 41 & 24 & 0.71 & $(0.62)$ & 33.5 & $(43.6)$ \\
\hline
\end{tabular}


Table 5 [R3Q1] [R3Q3]

Energetic content of microalgae according to two scenarii. S1: anaerobic digestion of the whole biomass, S2: digestion of biomass residues after lipids extraction.

749

\begin{tabular}{lcccccc}
\cline { 3 - 7 } & & $\begin{array}{c}\text { S1: Anaerobic digestion of } \\
\text { the whole algal biomass }\end{array}$ & \multicolumn{2}{c}{$\begin{array}{c}\text { S2: Anaerobic digestion of algal biomass } \\
\text { residues }\end{array}$} & $\begin{array}{c}\text { Energetic added value } \\
\text { with lipid recovery }\end{array}$ \\
\hline Species & $\begin{array}{c}\text { Growth } \\
\text { conditions }\end{array}$ & $\begin{array}{c}\text { Methane } \\
\text { (kJ/g VS) }\end{array}$ & $\begin{array}{c}\text { Methane } \\
(\mathbf{k J} / \mathbf{g} \text { VS) }\end{array}$ & $\begin{array}{c}\text { Lipids } \\
(\mathbf{k J} / \mathbf{g} \text { VS) }\end{array}$ & $\begin{array}{c}\text { Total energy } \\
(\mathbf{k J} / \mathbf{g} \text { VS) }\end{array}$ & $\begin{array}{c}\text { Additional energy } \\
(\mathbf{k J} / \mathbf{g} \text { VS) }\end{array}$ \\
\hline C.vulgaris & - & 23.0 & 20.1 & 6.6 & 26.7 & 3.7 \\
C.vulgaris & Low N & 24.9 & 17.2 & 14.7 & 32.0 & 7.1 \\
C.emersonii & - & 26.4 & 22.4 & 10.7 & 33.1 & 6.6 \\
C.emersonii & Low N & 33.1 & 27.6 & 23.2 & 50.8 & 17.7 \\
C.protothecoides & - & 23.4 & 21.8 & 4.1 & 25.8 & 2.4 \\
C.protothecoides & Low N & 25.5 & 22.2 & 8.5 & 30.7 & 5.2 \\
\hline
\end{tabular}

a: computed with a methane calorific value of $35.6 \mathrm{~kJ} / \mathrm{L}$.

b. computed with the calorific value of rapeseed crude oil : $36.87 \mathrm{MJ} / \mathrm{t}$,(Labeckas, 2009). 